\title{
Authorship and creation for university students
}

\section{Autoría y creación para estudiantes universitarios}

\section{Autoria e criação para estudantes universitários}

Graziele Aline Zonta ${ }^{1}$, ORCID 0000-0002-7908-7043

Andrea Vieira Zanella ${ }^{2}$, ORCID 0000-0001-8949-0605

\author{
${ }^{1}$ Universidade Federal do Paraná, Brazil \\ ${ }^{2}$ Universidade Federal de Santa Catarina, Brazil
}

\begin{abstract}
The aim of this study was to investigate the meanings of creation and the possibilities of authorship for students from two public universities. Reading and writing workshops with students, which were recorded via audio recordings and fieldnotes constituted the field of study. The analyses were based on the theoretical perspectives of Bakhtin and Vygotski and focused, from the students' point of view, on the social places institutionally occupied by professors and students and the meanings about the academic practices and their consequences for the possibilities of authorship and creation. The results indicate places of inequality in the relationship between peers from public and private education, the individual responsibilization of the students for their trajectories within the university and the signification of academic authorship as responsive to the productivist logic guided by the commodification of scientific production.
\end{abstract}

Keywords: university students; teaching practices; professor-student relationship; academic literacy; authorship.

Resumen: El objetivo de este estudio fue investigar los significados de la creación y las posibilidades de autoría para estudiantes de dos universidades públicas. Los talleres de lectura y escritura con estudiantes constituyeron el campo de investigación, que se grabaron mediante grabación de audio y notas en un diario de campo. Los análisis se basaron en las perspectivas teóricas de Bakhtin y Vigotski, y se centraron, desde la perspectiva de los estudiantes, en los lugares sociales ocupados institucionalmente por profesores y estudiantes y los significados de las prácticas académicas y sus consecuencias sobre las posibilidades de autoría y creación. Los resultados indican lugares de desigualdad en la relación entre pares de la educación pública y privada, la responsabilidad individual de los estudiantes por sus trayectorias en la universidad y la significación de la autoría académica como sensible a la lógica productiva guiada por la mercantilización de la producción científica.

Palabras clave: estudiantes universitarios; prácticas de enseñanza; relación profesoralumno; lectura y escritura académica; autoría. 
Resumo: O objetivo desta pesquisa foi investigar os sentidos da criação e as possibilidades de autoria para estudantes de duas universidades públicas. Oficinas de Leitura e Escrita com estudantes constituíram o campo da pesquisa, as quais foram registradas via gravação em áudio e anotações em diário de campo. As análises fundamentaram-se nas perspectivas teóricas de Bakhtin e Vigotski e tiveram como foco, sob a ótica dos estudantes, os lugares sociais ocupados institucionalmente por docentes e discentes e as significações sobre as práticas acadêmicas e seus desdobramentos nas possibilidades de autoria e criação. Os resultados indicam lugares de desigualdade na relação entre os pares provenientes do ensino público e privado, a responsabilização individual dos/as estudantes por suas trajetórias na universidade e a significação da autoria acadêmica como responsiva à lógica produtivista orientada pela mercantilização da produção científica.

Palavras-chave: estudantes universitários; práticas docentes; relação professor-estudante; letramento acadêmico; autoria.

Received: 02/27/2020

Accepted: 08/27/2021

How to cite:

Zonta, G. A., Zanella, A. V. (2021). Authorship and creation for university students. Ciencias Psicológicas, 15(2), e-2088. doi: https://doi.org/10.22235/cp.v15i2.2088

Correspondence: Graziele Aline Zonta, Universidade Federal do Paraná, Brazil. E-mail: graziele.zonta@ufpr.br

We are experiencing an intense movement in Brazilian universities in response to the public policies for access to and permanence in higher education. This mainly refers to the laws that came into force in the last decade, such as the Program for Supporting Plans for Restructuring and Expansion of Federal Universities (Reuni; Decreto-Lei $\mathrm{n}^{\circ}$ 6.096, 2007), Reservation of admission vacancies in the Federal Institutions of Education (Lei $\mathrm{n}^{\circ}$ 12.711, 2012), the Unified Selection System (SISU; Portaria normativa $n^{\circ} 21,2012$ ) and the National Student Assistance Program (Pnaes; Decreto-Lei $n^{\circ} 7.234,2010$ ). With these laws, higher education institutions opened their doors to social groups that historically had their educational possibilities limited to basic levels of education (Bisinoto \& MarinhoAraújo, 2011; Cerutti-Rizzatti \& Dellagnelo, 2016). However, this important movement in favor of democratizing access to higher education was accompanied by the emergence of conflicts in the relationships between students and professors, mediated by academic practices traditionally instituted in the reading and writing processes in the university context. 
In order to comprehend these tensions and contribute to the construction of public policies for student permanence in the university, we problematize, with this study, the meanings of creation and the possibilities of authorship for university students from different social realities that were beginning their academic trajectories. We start from the historical-cultural perspective of constituting subjectivity to conceive the creative activity as a human action that produces culture (Vygotski, 1992; 2009). Authorship, in turn, is understood as the axiological, ethical and aesthetic positioning of subjects in relationships that objectify, in their productions, their assessment of the world (Bakhtin, 2003; 2013).

Reading and writing are the main activities that constitute the academic literacy practices of authors and creators in the university context. Based on this comprehension, the results of reading and writing workshops conducted with university students in two public Brazilian universities are analyzed here. ${ }^{1}$ Characterized as an intervention study (Zanella, 2017), the objectives of the workshops were: to produce, together with the students, meanings about different texts; to exercise forms of writing in addition to those commonly proposed in the academic context; and to engender discussions, based on the exercise of reading-writing, about how these practices happen in the university and how they mediate the relationships among the students and between the students and professors.

\section{Method}

The work method of the workshops consisted of collective readings of literature texts, social networks, videos and other materials, followed by conversation circles (Branco \& Pan, 2016) that sought to promote the production and the sharing of meanings about the material accessed, articulating it to perceptions about the conditions under which academic reading and writing occurs in the university. The participants were invited to produce texts in different formats and discursive genres and to comment on their productions and the process of their creation.

In addition to the requirement to be undergraduate students, other criteria were not defined for the selection of the workshop participants, which resulted in groups formed by students of different teaching centers and periods. Two groups were held in Universidade Federal de Santa Catarina (UFSC) and one group in Universidade Federal do Paraná (UFPR), with the number of meetings varying between six and eight and the number of participants between three and ten. Students aged between 18 and 49 years participated. All the students that agreed to participate in the study signed a consent form and were able to choose to have their names or initials disclosed, or to create a pseudonym to be used in the research report. The study was approved by the Ethics Committee for Research with Human Subjects (Cepsh) of UFSC.

The discourses produced during the conversation circles were audio recorded, transcribed and analyzed, together with the texts created during the meetings and the fieldnotes made by the workshop mediator. The analysis was based on Bakhtin's dialogical perspective $(2012 ; 2013)$ and Vygotski's fundamentals $(1992 ; 2009)$. Two themes stood out during the analysis of the material: 1) the recognition of the different places occupied

\footnotetext{
${ }^{1}$ The reading and writing workshops constituted the study field for the doctoral thesis of the first author, carried out under the supervision of the second author.
} 
institutionally by professors and by students from different educational and social contexts; 2) the meanings produced about the academic practices and their consequences as possibilities for authorship and creation.

\section{Results and Discussion}

\section{The mark of the difference and the discourse of the discrepancy}

Discursive fields are constructed through relatively stable ways of saying, acting and being, constituted in/by the language that circulates among its participants, formed according to discursive genres specific to each context and situation (Bakhtin, 2003; Haye \& Larrain, 2018). Geraldi (2014) articulated the concepts of literacy and discursive genres when considering this as the process of learning the ways of using language. In this way, we understand academic literacy practices as learning how to say, act and be in the discursive context of higher education. These practices tend to conflict with previous literacy practices (Alves \& Moura, 2016), making it necessary to take into account the students' experiences with reading and writing in the learning process in higher education.

As Rama (2015) analyzed, academic knowledge in Latin America has historically been linked to the occupation of places of power accessible to specific portions of the population with greater purchasing power. In Brazil, this condition was associated with the low quality of public elementary and high school education, which limited the conditions of access to quality public higher education. As a consequence, entry into the best Higher Education Institutions (HEIs) remained, for decades, restricted to students from private educational institutions who, more easily, adapted themselves to the HEI practices.

Tensioning this condition, the increase in the entry of students from the lower classes into universities, as a result of access policies, destabilizes the standards and practices naturalized by the participants in the academic context, requiring their review (Cerutti-Rizzatti \& Dallagnelo, 2016). To problematize this context from the perspective of students, we present below the statements of two participants in the reading and writing workshops. Both came from public schools and joined UFSC to attend the Literature course. Their statements reveal the recognition of the unequal conditions with which they entered higher education and with which they face reading and writing practices, the appropriation of academic genres and the methods of evaluation in their courses:

The university excludes the issue of social diversity. The entrance exam is for everyone and there is the question that some students come from a top school... And others do not. And then it is as if the professor and the institution were giving the exam only for those students who had the opportunity to have a good high school education. (Lorena, Literature, 7th phase, UFSC).

The professors assume that all students had very good schooling, that they came from an excellent high school and they no longer need to teach this. [...] I have trouble writing. I'm suffering. I have difficulty bringing ideas together, understanding what a narrative is, a short story, reviews, essays, the ABNT [Brazilian Technical Standards Association] rules. [...] They expect 
that those who are at the Federal University already have all this preparation, that they already have those three years of excellent high school education. (STR, Literature, 2nd phase, UFSC).

Considering the relationship between the ways of teaching and learning, as they are signified by these students, we perceived special contours in the contrast between the conditions of their fellow students. When experiencing the difficulties inherent to the academic context, the students recognized a place of inequality in the relationship with their peers, however, they also seemed to unify the responsibility for the challenges faced in the failures of the previous educational stages. This meaning is produced in the students' concrete experience, however, reproduces the social meaning that currently runs through the discussions about access and permanence at the university (Almeida \& Pan, 2017).

According to Zavala (2010), in the context of a dominant intellectual and cultural tradition, groups of students from other cultural traditions face obstacles that seem to be unknown (or unconsidered) by the professors. In this process, a "normative formulation" is created (p. 90) which defines that the good students are those that most easily move towards what is expected of them, in terms of academic performance, already upon their admission. For the others there is an exclusion process that reserves them the place of deficiency, discrepancy and deficit that starts to compose their discursive production. This statement directly articulates the conditions of fundamental education, mainly in the public school, to the supposed cognitive and emotional difficulties of the students and/or to family contexts that would not promote good reading and study habits.

It should be highlighted that the previously cited statements include not only the fact that the students feel a discrepancy when compared to other students, but also the impression that the classes are not directed toward them, but toward those that more easily overcome the challenges of academic literacy. When STR mentioned the difficulties he faced in the course, such as learning academic genres and formats, such as those of the $\mathrm{ABNT}$, he was commenting on learning that, in principle, is specific to higher education in the Brazilian educational context. In spite of this, his statement seems to link his difficulties solely to the fact that he did not go through "those three years of excellent high school" at the private school, responding to and substantiating, in this way, discourses that neglect the university's responsibility for the training of students in their own academic practices.

The statement, transcribed below, of Alba, a law student at UFPR and from a rural public school, reinforces meanings of disorientation and helplessness interwoven in the articulation between the meaning produced about discrepancy, the complexity of the readings included in her course and the difficulties of appropriating academic genres:

In the high school education there is a very large discrepancy in reading and writing and at university the professors push us to write articles. So I find myself having to write an article and I don't even know where to start. And then you are also faced with complicated reading. Durkheim and Marx are very complicated reading for those that are now starting to read texts of this type. And this pressure for us to write well, read a lot, leaves us disoriented and there is no support at all. (Alba, Law, 2nd phase, UFPR). 
The intricate process described by Alba reaffirms the perception that the overcoming of academic obstacles has been delegated, by the HEIs, to individual students, since pedagogical practices seem to assume that these students should already bring from previous levels of education all the knowledge necessary to respond to any demands that academic literacy imposes on them. However, it is necessary to evaluate that the reading of works by authors such as Marx and Durkheim, as mentioned by Alba, would probably not have been carried out before entering the university by any student, coming from public or private Brazilian education. Despite this, also for Alba, her difficulty is signified as a direct result of the "very large discrepancy in reading and writing" that she had due to her high school education.

In addition to affirming the denial of the relational condition of the educational process, when the students are delegated to assume alone the implications of their academic success/failure, at the same time that they are assigned a place of discrepancy or deficiency, the knowledge and skills that they take with them to the university are made invisible and their supposed faults and shortcomings are valued. In this sense, what the student knows does not seem to find space in the academic context, as this knowledge is alien to the contents and formats that circulate in the disciplines.

\section{The usucaption of the university}

Jefferson, a student of the Mechanical Engineering course at UFPR, a course that, like other engineering courses, presents disciplines with high levels of reproval, also expressed in his statements meanings about the distances established between the institution and students. In the statement transcribed below, the student exemplifies how, in his course, the process of holding the student accountable for academic success or failure surpasses the classroom practices and is extended to the academic and institutional organization:

There was even a situation recently... that the people were enrolling and a girl went to ask the coordinator if he could put on an extra class for a certain discipline [...] if he could put on another class, because there were a lot of people failing the discipline. Then the professor said: "We are not going to do that, this is not our problem. You should have rethought your choices so that you didn't fail any discipline and now you would not have a problem". (Jefferson, Mechanical Engineering, 6th phase, UFPR).

We also heard in Jefferson's speech, meanings constructed around a logic that seems to release the university from rethinking institutional policies and practices. The planning of a project to be perfectly followed in the university, from the beginning of the academic trajectory, seems to be entrusted to the students, as if the fact of failing in subjects was for them a matter of choice or disorganization. In addition, we heard in his speech an expectation that this trajectory will occur fully ordered, with control and without stumbling blocks.

In this sense, it seems that the aforementioned course obeys a concept of learning as a linear, cumulative process, composed of sequenced and pre-fixed stages, which students always need to follow rigorously and successfully, with the risk of being reproved, that is, 
of not being able to enroll in mandatory subjects without having been approved in previous subjects placed as prerequisites for the following ones. For this situation, the course does not seem to provide alternatives.

When we focus on this issue from the historical-cultural perspective in psychology, we observe that the condition placed on these students is incoherent. From Vygotski (1992) we comprehend that the construction of higher psychological processes takes place in a relational way, between people in certain social contexts, semiotically mediated. Different contexts and relationships engender different processes of subjective, cognitive and affective construction, in a dialectical movement between collective and singular that is not linear or sequential, but interwoven by tensions, ruptures and contradictions. Learning is, therefore, intertwined with the conditions of the social context in which it takes place, a process that needs to be evaluated in all educational stages, including higher education, since it is also a subject undergoing development, as Marinho-Araújo (2016) analyzes well.

Perhaps more significantly, the meaning that unfolds from Jefferson's statement is that, in view of the professors' place of voice and authority and their determinations, students feel powerless, a meaning that was similarly reported in the statements by participants from other groups of the workshops. We highlight below a dialogue between Ana Maria, a student from the 7th phase of the Literature course, and Dhara, from the 1st phase of Pedagogy, both at UFSC, which occurred when the conversation circle discussed the possibilities of requesting changes in the practices of their professors:

Ana Maria: There are some professors who already have a usucaption ${ }^{2}$ from the university and they do what they want and they have another position. So, how do we fight with a professor like that?

Dhara: Actually, there's not much we can do, right? We don't have any way to complain. I still don't know where we are going to complain because we are going to talk to the professor and he doesn't accept criticism.

When she mentions "another place", referring to the place occupied by professors, Ana Maria alludes to a condition of power that allows them apparently unquestionable actions. The student still uses, as a resource illustrative of this condition, the acquisitive prescription process and compares the professor's place to the law of usucaption, indicating that she perceives that certain professors have acquired the property of their place of power in the university, being able to enjoy and dispose of it, regardless of the other participants of this space. Like the professor mentioned in Jefferson's statement, they make use of this place in order to deny any possibility of dialogue, of difference or of their practices being modified. The problem is the other, in this case, the student.

\footnotetext{
${ }^{2}$ In Article 1238 of the Brazilian Civil Code (Lei ${ }^{\circ}$ 10.406, 2012), possession by usucaption is explained as: "Whoever, for fifteen years, without interruption, or opposition, possesses a property, as their own, acquires the property, regardless of title and good faith".
} 
What Jefferson, Ana Maria and Dhara offer us are concrete examples of how the power relations structured at the university configure possibilities of action that are crossed by the recognition that the social place of the professors is unmoved by changes, receiving the effects of a law against that which does not appear to have resources. Their statements resound with presumptions that, in their place as students, they are subjected to transforming their possibilities of acting, saying and being, in obedience and silence.

\section{How, for whom and for what to write?}

Research, internship and university extension reports come into existence in the academic community when published in books, chapters, annals of events or scientific journals, with each publication adding a new item to the curriculum of its author and expanding their possibilities of speaking and being heard by their peers. This dynamic participates in the construction of the different places of knowledge/power occupied by participants in the academic-university context, making their practices visible.

In the institutional hierarchies, the prominent place of knowledge/power is occupied by the professor. It is the professor that publishes the texts to be read by the students and that defines the evaluation criteria for their disciplines. Therefore, this professor is the figure for whom the student's writing is historically proscribed, which makes him/her the authority in this field. The students' statements, or what they can say and the way they should say it, are produced in the relationship with this special interlocutor, they respond and address him. This constructs a discursive space filled with "dialogical resonances" (Bakhtin, 2003, p 300), that is, the reflection and refraction of the voices that intertwine in the chain of statements that constitutes the discursive communication.

We can deepen these resonances based on the statement of Thais, a student from the 1st phase of the Literature course at UFSC, when discussing the difficulties, she faced when producing written work:

Each professor likes you to do that work, be it an abstract or whatever, in a particular way. When he gives you guidance on how he wants it, it makes it easier. But when he leaves you alone, without even saying: "Look, do it this way", you are insecure. We did a lot of abstracts, we haven't had any responses yet. There's more to do and we are: "But am I doing it right?" Okay, university is a place where you are more by yourself, you can't count on the professor, but at least he'll give you guidelines for what he wants... To say: "Look, I want you to elaborate more on this, this and that". And when you don't have this, you're very lost, very insecure. (Thais, Literature, 1st phase, UFSC).

Perhaps the abstract format is among the textual productions most requested from undergraduate students, being frequent in the Literature course at UFSC, according to the information of the students in the workshop. But Thais' speech revealed different possibilities for its realization, stating that when requesting abstracts, professors place certain expectations on the students' production. These expectations are not obvious, but they seem to be presumed in the professors' request, leading to the recognition of what Bianchetti (2012, p. 248) called the mark of the pre-formatted order. For the author, the 
commissioning of the work creates a kind of tacit contract between professors who provide the content and students who receive that content to then return it to the professors in the format of assessment tasks. For Thais, the doubts culminate in insecurity regarding her productions and reinforce requests for explanations about "how to do" the activities in order to respond to the assumed requirements of the professors.

The origin of the feeling of insecurity that accompanies the preparation of academic work can be traced to the first stages of formal schooling. For Zanella (2017), the schooling process that from its early years invests primarily in the consumerist/reproductivist logic, a logic marked by the accumulation of information and the reproduction of forms and styles, distancing itself from the process of its own production and diffusion, produces effects that persist in higher education. From a Bakhtinian reading, the author states that investing in creative processes that favor an inventive posture is fundamental for the construction of authorship: "The dialogue with different perspectives is necessary, as is the interpenetration that makes it possible to understand their specificities and is configured as a foundation for the important movement of displacement and differentiation" (p. 209).

In Thais' situation, the pedagogical mediation of the professors would be necessary for the immersion in the different modes of creation and the explanation of the teaching expectations, according to the activities requested, in order to favor the reflected, active and inventive creation of academic work.

In addition to the doubts about the concrete process of how to do the requested activities, what is worrying in Thais' statement is the meaning that the university experience must be lived in a solitary way, and the student cannot count on the professor. It is important to problematize the ways of constructing this mode of thinking, as we recognize that the academic space is constructed by the relations that mediate the processes of teaching-learning and by the collective construction of knowledge and actions in situations of experience, this movement being decisive for the results obtained by the students in their trajectories.

It is also important to highlight that the concern with expressing oneself in the way that the professor wants establishes itself as tension in the student's production, defining the parameters for a good or bad text. In this process, in addition to the possibility of awarding good grades as a result of the student's work, the successful academic production of students becomes a value of exchange for places in research projects, for participation in scientific events, for entry into postgraduate courses, for the expansion of the curriculum and for the publication of articles in partnership with the professors, having their names cited and referenced by their peer-authors.

Even though they crave the recognition of professors and the opportunities that this recognition makes possible, the consequences of this partnership with the professor are not always clear for the students in relation to the authorship and publication of their work. Such an aspect can be analyzed from the statement of Júlia, a student of the 6th phase of Nursing at UFSC, when she commented on a situation in which she felt that the authorship of her work was not respected:

Julia: I wrote an article. The professor corrected it and she asked to add the names of four more people... And four professors! So, me and five professors were the authors of the article. But the professors did nothing. 
With this discussion, we do not want to disqualify the practice of co-authorship between professors and students, which provides a possibility for creation and learning for both. Joint publication not only helps students to register their names in publications, but also to insert them in the academic field of discourse, to dialogue with their peers, to reflect on, share and produce knowledge. We are also aware that the voice of the professor, the knowledge taught by him/her and its analysis are appropriated by the students, who, in turn, "remove the quotation marks" 3 when they write their work.

The teaching authorship needs to be recognized in the student's work, however, the conditions of authorship of each part, according to Julia's statement, are not clear to the students. We believe that these disagreements, among other reasons, respond to the conditions that are placed on the teaching work that, in the current academic-university structure, in its relations with development agencies and institutions of excellence evaluation, impose a strong demand for the number of publications, supervisions and projects.

This is the reality that results from the logic of commodification of the relations of the professor's work, as discussed by Mancebo (2010). In her study, the author addresses the neoliberal reforms implemented since the 1990s in the policies aimed at Brazilian higher education, in which procedures resulted in the "intensification and extension of the work, relating it to market demands and/or logic" ( $p$.80). As a consequence of this logic, Meksenas (2012) discussed the current production of significant numbers of intellectuals adhering to the status of the profession and engaged in research and publications that serve more the career advancement and less the critical and militant capacity, in a movement that culminates in a distance between theory and practice.

In this scenario, it is not inconceivable that professors also feel pressured or threatened, a condition that interferes in the relationship with students and in the authorization that is given, or denied, to participate in the scientific-academic dialogue. As Tovar (2015) analyzed in his study on the relationship between students and professors at a Brazilian federal university, the link between teaching work and productivist parameters is the reason why professors are valued for what they do outside the classroom, that is, the number of productions, supervisions and disciplines, thus being invited to "evade the encounter with the student" (p. 82).

\section{Academic productivism and individualistic authorship}

The partnership between authors, the exchange of experiences and knowledge necessary for the construction of knowledge and the understanding of the historical process of their production, which, we understand, are indispensable for student education, are important points of reflection on authorship in the academic-university context. However, according to the participants' statements, these processes seem to give way to the meaning

\footnotetext{
${ }^{3}$ For Bakhtin $(2003,2013)$, we introduce the words of the other in our speech, covering them with our comprehension, so that they become bivocal. In the words of others, we can reinforce our own words, cover them with our own intentions, or merge them entirely with our voice, forgetting their origin, removing their quotation marks.
} 
of the authorship as a result of the individual effort that would determine the name that will be printed in the next publication.

Lucas, a student of UFSC, identified how this way of thinking takes place in the field of Physics, his undergraduate course:

I think that science is cruel because it tries to value the individual. They do not try to value the development of the entire study, of everyone who participated: "I want my name to be there" and they don't think much about the development. (Lucas, Physics, 1st phase, UFSC).

Lucas recognized that the researcher's work is not solitary, as it involves groups of people who become responsible for the results produced. However, he noted that for many fellow students it would not be enough to participate in the study, with it being necessary to stand out from the rest. Having the name printed in the study is an ambition that goes before being part of the collective construction of the research.

We highlight this desire or the claim of individual authorship detached from the other, from the word of others, as an unrealizable aspiration, since the knowledge is necessarily constructed in a process and is based on the works of others that preceded its producer/author. On this point, Vygotski (2009) stated: "No invention or scientific discovery can occur before the material and psychological conditions necessary for it to occur have appeared. Creation is a historical, cumulative process where every succeeding manifestation was determined by the preceding one" (p. 42).

Great creations by great authors are supported by small creations by anonymous authors, because "an enormous percentage of what has been created by humanity is a product of the anonymous collective creative work of unknown inventors" (Vygotski, 2009, p. 16). When this collective process of creation is disregarded, the intersubjectivity of all creative work is denied and competitiveness is established, which in turn strengthens the meritocratic logic by gratifying those who publish the most.

Perhaps there is confusion in the statements of the participants between the sense of authorship, such as the positioning of voices that, from a dialogical construction, become concrete in an enunciation, such as the academic text, and public recognition as a social place that responds to the logic of the market, of the publicity, of the insertion in the complex web of communication that produces ephemeral successes. The recognition so desired should not, therefore, be the objective of the participants in the academic context, but rather the consequence of a significant authorial production combined with the conditions that participate in this production.

Fernanda, a Geography student at UFSC, also reported how she observed the action of the same logic and its effects on the academic activities in her area of training. In the statements transcribed below, she signifies the participation of colleagues in scientific events:

What a thing! Sometimes I hear someone saying: "Ah! We will send any abstract [to an event]. Send it! Write anything there! Send an abstract there because they approve everything and then we get on with it and do it".

$[\ldots]$ 
For me, it is a pleasure to be in these environments. But on the other hand, I see colleagues going to these places just to get the certificate, you know? They are just worried about the hours, they don't even say: "I was part of that", understand? [...] Then you see that you are losing the passion in your profession, in the discussion [...]. Then this passion starts to dies, the university seems to be killing it. [...] My professor says: the university makes people sick. People often start to suffer depression at the university. So we have to pay attention to that, do things that give pleasure in life. Living without meaning is terrible! (Fernanda, Geography, 8th phase, UFSC).

In her statements, Fernanda illustrated how, in addition to enabling the registration of authorship in academic publications, participation in events assumes the function of generating certificates with registration of hours of participation in activities, a requirement in the undergraduate courses. However, for this, colleagues stop doing activities that interest them to participate in events for which they are not motivated. The meanings of taking part, of participating in the discussions, of the exchanges proposed in these events are lost, as is the enthusiasm for the training itself, culminating in a process of illness that the student, through the voice of her professor, defined as depression.

Fernanda's statements again problematize the process of exclusive accountability of the students for their academic successes or failures, as we discussed in the previous item. When she says that "the university seems to be killing it"; "The university makes people sick", Fernanda recognized that the so-called depression is not a condition that students necessarily bring with them to the university. On the contrary, it can be produced after enrolment, in the struggle that students have to succeed in academic activities, not only in the production of evaluative activities, but also in the attempt to participate in the greatest number of activities possible, which in turn will revert to new publications, opening spaces and greater visibility in their fields of study. Thus, the university inserts its students in the logic of production and conditions their possibilities of authorship.

\section{Conclusions}

The moment different groups enter the public university, new demands and old conflicts in the relationships between the participants of the academic arena surface. Among students from public schools, the difficulties appear in the comparison with colleagues better prepared for higher education and are discursively identified in the discrepancy that would be produced by the low quality of the previous levels of education. Coping with this condition becomes more laborious when the university omits its responsibility in the institution of the students' difficulties and in the construction of strategies for overcoming them, delegating the duty of facing the academic challenges exclusively to them. 
Obviously, it is not possible for the students to reconstruct their school trajectory, to take individual responsibility for correcting flaws in the previous levels, which are the result of a complex process that disarticulates the socio-cultural conditions of access to quality fundamental, high school and higher levels of education and to the public and private spheres. When they enter higher education, it is the university context that they have access to, and universities need to be prepared to welcome them, with their differences.

Denial of responsibility is the alternative generally used when the institution does not seem to know how to solve the difficulties that are posed to them or that they create themselves. However, this alternative is cruel, as it leans towards the historically subdued side in the tense arena of social relations. It is also the least effective if the objective is not only to guarantee access, but also permanence and academic success.

In the unequal struggle to make themselves heard in the academic arena, we recognize the effort that students have made to insert themselves in the logic driven by the policies of high production imposed on and transmitted by their professors. In this process, authorship is outlined by the number of publications and the significance of the academic work as a result of individual effort, exacerbating a highly competitive process among the peers themselves. In this scenario, it is necessary to question how we can construct practices that value student academic production and teacher participation in this production. Practices that contribute to effective co-authorship between professors and students, that favor the training of student-authors, but that, at the same time, highlight the mercantilist logic that guides the production of knowledge in the university context.

\section{References}

Almeida, A. B. \& Pan, M. A. G. S. (2017). Contribuições bakhtinianas para o estudo das práticas de leitura e escrita na universidade: autoria, gêneros científicos e identidade profissional. In M. A. G. S. Pan; L. Albanese \& N. L. Ferrarini (eds.), Psicologia e educação superior: formação e $(m)$ prática (pp. 75-98). Curitiba: Juruá.

Alves, M. F. \& Moura, L. O. B. M. (2016). A escrita de artigo acadêmico na universidade: autoria x plágio. Ilha do Desterro, 69(3), 77-93. doi: https://doi.org/10.5007/21758026.2016v69n3p77

Bakhtin, M. (2003). Estética da criação verbal (4a ed.). São Paulo: Martins Fontes.

Bakhtin, M. (2012). Para uma filosofia do ato responsável (2a ed.). São Carlos: Pedro \& João Editores.

Bakhtin, M. (2013). Problemas da poética de Dostoiévski (5a ed.). Rio de Janeiro: Forense Universitária.

Bianchetti, L. (2012). O processo da escrita: elementos inibidores e facilitadores. In: L. Bianchetti \& P. Meksenas (eds.), A trama do conhecimento: teoria, método e escrita em ciência e pesquisa (pp. 239-265). Campinas: Papirus.

Bisinoto, C. \& Marinho-Araújo, C. M. (2011). Psicologia escolar na educação superior: atuação no Distrito Federal. Psicologia em Estudo, 16(1), 111-122. doi: http://dx.doi.org/10.5935/1980-6906/psicologia.v18n3p156-167

Branco, P. I. \& Pan, M. A. G. S. (2016). Rodas de conversa: uma intervenção da psicologia educacional no curso de medicina. Revista Psicologia: Teoria e Prática, 18(3), 156167. doi: http://dx.doi.org/10.5935/1980-6906/psicologia.v18n3p156-167 
Cerutti-Rizzatti, M. E. \& Dellagnelo, A. C. K. (2016). Desafios à educação para a autoria na esfera acadêmica. Ilha do Desterro, 69(3), 63-76. doi: http://dx.doi.org/10.5007/2175-8026.2016v69n3p63

Decreto-Lei $\mathrm{n}^{\circ}$ 6.096, de 24 de abril e 2007. (2007). Institui o Programa de Apoio a Planos de Reestruturação e Expansão das Universidades Federais (Reuni). Diário Oficial da União. Retrieved from http://www.planalto.gov.br/ccivil_03/_ato20072010/2007/decreto/d6096.htm

Decreto-Lei no 7.234, de 18 de julho de 2010. (2010). Dispõe sobre o Programa Nacional de Assistência Estudantil (Pnaes). Diário Oficial da União. Retrieved fromhttp://www.planalto.gov.br/ccivil_03/_Ato20072010/2010/Decreto/D7234.htm

Geraldi, J. W. (2014). A produção dos diferentes letramentos. Bakhtiniana, 9(2), 25-34.

Haye, A. \& Larraín, A. (2018). Campo e enunciado: problema da articulação do discurso. Bakhtiniana, 13(2), 79-99.

Lei n ${ }^{\circ}$ 10.406, de 10 de janeiro de 2002. (2002). Institui o Código Civil. Retrieved from http://www.planalto.gov.br/ccivil_03/leis/2002/L10406.htm.

Lei no 12.711, de 29 de agosto de 2012. (2012). Dispõe sobre o ingresso nas universidades federais e nas instituições federais de ensino técnico de nível médio e dá outras providências. Diário Oficial da União. Retrieved from http://www.planalto.gov.br/ccivil_03/_ato2011-2014/2012/lei/112711.htm.

Mancebo, D. (2010). Trabalho docente na educação superior brasileira: mercantilização das relações e heteronomia acadêmica. Revista portuguesa de educação, 23(2), 73-91. doi: https://doi.org/10.21814/rpe.13987

Marinho-Araújo, C. M. (2016). Inovações em psicologia escolar: o contexto da educação superior. Estudos de Psicologia, 33(2), 199-211. doi: https://doi.org/10.1590/198202752016000200003

Meksenas, P. (2012). Ideologia, intelectuais e dogmatismo na ciência. In L. Bianchetti \& P. Meksenas (eds.). A trama do conhecimento: teoria, método e escrita em ciência e pesquisa (4a ed., pp. 57-72). Campinas: Papirus.

Portaria normativa $\mathrm{n}^{\circ} 21$, de 5 de novembro de 2012. (2012). Dispõe sobre o Sistema de Seleção Unificada (SISU). Diário Oficial da União, nº 214, Brasília-DF, 06 de nov., 2012. Retrieved from http://static07.mec.gov.br/sisu/portal/data/portaria.pdf

Rama, A. (2015). A cidade das letras. São Paulo: Boitempo.

Tovar, A. (2015). A relação professor-estudante na universidade pública. Uma leitura bakhtiniana (Dissertação de mestrado). Universidade Federal do Paraná, Curitiba, PR, Brasil.

Vygotski, L. S. (1992). Obras escogidas II: pensamiento y lenguaje. Madrid: Visor Distribuciones.

Vygotski, L. S. (2009). Imaginação e criação na infância: ensaio psicológico: livro para professores. São Paulo: Ática.

Zanella, A. V. (2017). Entre galerias e museus: diálogos metodológicos no encontro da arte com a ciência e a vida. São Carlos: Pedro \& João Editores.

Zavala, V. (2010). Quem está dizendo isso? : letramento acadêmico, identidade e poder na educação superior. In: C. Vóvio, L. sito \& P. De Grante (eds.), Letramentos: rupturas, deslocamentos e repercussões de pesquisas em linguística aplicada (pp. 7195). Campinas, Mercado das Letras. 
Authors' participation: a) Conception and design of the work; b) Data acquisition; c) Analysis and interpretation of data; d) Writing of the manuscript; e) Critical review of the manuscript.

G. A. Z. has contributed in a, b, c, d, e; and A. V. Z. in a, c, d, e.

Scientific editor in charge: Dra. Cecilia Cracco. 